Jurnal Gizi Klinik Indonesia

Vol. 16 No. 1, Juli 2019 (1-13)

ISSN 1693-900X (Print), ISSN 2502-4140 (Online)

Tersedia online di https://jurnal.ugm.ac.id/jgki

DOI: https://doi.org/10.22146/ijcn.34560

\title{
Pengetahuan, sikap, motivasi ibu, dan praktik pemberian MP-ASI pada anak usia 6-23 bulan: studi formatif di Aceh
}

Maternal knowledge, attitude, motivation and complementary feeding practice of children aged 6-23 months: formative study in Aceh

\author{
'Jurusan Gizi, Politeknik Kesehatan Kementerian Kesehatan Aceh \\ 2 Departemen Gizi Masyarakat, Fakultas Ekologi Manusia Institut Pertanian Bogor \\ ${ }^{3}$ Universitas Islam Negeri Syarief Hidayatullah Jakarta
}

Aripin Ahmad ${ }^{1}$, Siti Madanijah², Cesilia Meti Dwiriani' ${ }^{2}$, Risatianti Kolopaking ${ }^{3}$

\begin{abstract}
Background: Poor knowledge, attitude, and motivation of the mother determine complementary feeding (CF) practice of the child resulting in poor nutrition fulfillment. Objective: This study aimed to analyze maternal knowledge, attitude, motivation, and their relationships with CF practice of children aged 6-23 months. Methods: A cross sectional study and cluster random sampling was applied to select 392 mothers of children aged 6-23 months in Aceh Besar District. Data on maternal knowledge, attitude, and motivation were collected using valid and reliable structured questionnaire. CF practice quality was assessed using indicators of timely introduction to $\mathrm{CF}$, minimum meal frequency, minimum dietary diversity, and minimum acceptable diet according to WHO recommendation. The association of maternal knowledge, attitude and motivation with CF practice was analyzed using binary logistic regression with 95\% of confidence level $(\alpha=0.05)$. Results: There was small proportion of mothers $(20.2 \%, 8.7 \%, 33.9 \%)$ having good knowledge, attitude, and motivation, respectively. Overall, there was one-fourth (23\%) of the children aged 6-23 months receiving $C F$ as recommended by WHO. There were significant correlations between maternal knowledge and attitude $(r=0.606, p<0.01)$ and motivation $(r=0.103, p<0.05)$. Education level and motivation were the risk factors of improper $C F$ practice $(O R=4.25 ; 95 \% C I: 1.10-16.36 ; p=0.035$ and $O R=1.83 ; 95 \% C I: 1.05-3.16 ; p=0.031$, respectively). Conclusions: Maternal knowledge, attitude, and motivation of children aged 6-23 months in Aceh were still poor, shown by improper CF practice. Therefore, effort to improve nutrition education, particularly by health personnel and stakeholder, to be specific and targeted is important.
\end{abstract}

KEYWORDS: appropriate complementary feeding practice; attitude; infant 6-23 months old; knowledge; motivation

\begin{abstract}
ABSTRAK
Latar belakang: Pengetahuan, sikap, dan motivasi ibu yang kurang akan menentukan praktik pemberian MP-ASI pada anak dan berdampak terhadap pemenuhan gizi. Tujuan: Penelitian ini bertujuan menganalisis pengetahuan, sikap, motivasi ibu, dan hubungannya dengan praktik pemberian MP-ASI pada anak usia 6-23 bulan. Metode: Desain cross-sectional terhadap 392 ibu yang mempunyai anak usia 6-23 bulan di Kabupaten Aceh Besar dan diambil secara cluster random sampling. Pengetahuan, sikap, dan motivasi ibu dikumpulkan dengan kuesioner terstruktur yang telah diuji validitas dan reliabilitas. Kualitas praktik pemberian MP-ASI menggunakan indikator kesesuaian waktu pemberian MP-ASI (timely introduction complementary feeding), frekuensi makan (minimum meal frequency), keragaman (minimum dietary diversity), dan pemberian MP-ASI yang adekuat (minimum acceptable diet) sesuai rekomendasi WHO. Analisis hubungan pengetahuan, sikap, dan motivasi ibu dengan kualitas praktik pemberian MP-ASI digunakan regresi logistik biner pada tingkat kepercayaan $95 \%(\alpha=0,05)$. Hasil: Hanya sebagian kecil ibu yang mempunyai pengetahuan, sikap, dan motivasi yang baik dalam praktik pemberian MP-ASI (20,2\%; 8,7\%; 33,9\%). Kurang dari seperempat $(23,4 \%)$ anak usia 6-23 bulan yang memperoleh praktik pemberian MP-ASI yang tepat sesuai rekomendasi (appropriate complementary feeding). Terdapat hubungan signifikan antara pengetahuan dengan sikap $(\mathrm{r}=0,606 ; \mathrm{p}<0,01)$ dan motivasi ibu $(\mathrm{r}=0,103 ; \mathrm{p}<0,05)$. Tingkat pendidikan dan motivasi ibu merupakan faktor risiko praktik pemberian MP-ASI yang tidak tepat $(\mathrm{OR}=4,25 ; 95 \%$ CI:1,10-16,36; $\mathrm{p}=0,035$ dan $\mathrm{OR}=1,83 ; 95 \%$ CI: 1,05-3,16; $\mathrm{p}=0,031)$. Simpulan: Pengetahuan, sikap,
\end{abstract}

Korespondensi: Aripin Ahmad, Jurusan Gizi Politeknik Kesehatan Kementerian Kesehatan Aceh, Jl. Soekarno Hatta Darul Imarah, Aceh Besar, Aceh, Indonesia, Telp. 08126939592,e-mail: aripinahmad@poltekkesaceh.ac.id

Cara sitasi: Ahmad A, Madanijah S, Dwiriani CM, Kolopaking R. Pengetahuan, sikap, motivasi ibu, dan praktik pemberian MP-ASI pada anak usia 6-23 bulan: studi formatif di Aceh. Jurnal Gizi Klinik Indonesia. 2019;16(1):1-13. doi: 10.22146/ijen.34560 
dan motivasi ibu di Aceh dalam praktik pemberian MP-ASI pada anak usia 6-23 bulan masih tergolong kurang dan terlihat pada sebagian besar praktik pemberian MP-ASI yang tidak tepat. Perlu upaya peningkatan melalui program edukasi gizi yang spesifik, terstruktur, dan tepat sasaran oleh petugas kesehatan.

KATA KUNCI: praktik pemberian MP-ASI; sikap; bayi 6-23 bulan; pengetahuan; motivasi

\section{PENDAHULUAN}

Praktik pemberian makanan pendamping air susu ibu (MP-ASI) merupakan faktor penting untuk pemenuhan kebutuhan gizi anak karena mulai usia 6 bulan terjadi ketimpangan gizi antara jumlah yang dibutuhkan dengan energi dan zat gizi yang tersedia dari ASI sehingga harus dipenuhi dari MP-ASI $(1,2)$. Kekurangan asupan gizi dari MP-ASI pada anak usia 6-23 bulan menyebabkan terjadinya gangguan pertumbuhan dan tingginya risiko menderita stunting (3). World Health Organization (WHO) menyatakan sekitar 32\% anak usia balita di negara-negara berkembang menderita stunting dan 10\% wasting disebabkan oleh MP-ASI yang tidak optimal (3). Di Indonesia, hampir 9 juta atau $37 \%$ anak balita menderita stunting sehingga Indonesia berada di urutan kelima dengan prevalensi stunting terbesar di dunia (4) dan Aceh menduduki peringkat ketiga dengan prevalensi stunting pada balita $(37,3 \%)$ dan peringkat pertama pada anak usia di bawah dua tahun (37,9\%) (5).

Salah satu penyebab langsung terjadinya kekurangan gizi dan stunting pada anak khususnya pada anak usia 6-23 bulan adalah praktik pola pengasuhan yang tidak tepat, salah satu indikatornya adalah praktik pemberian MP-ASI yang tidak optimal. Data WHO menunjukkan hanya sepertiga dari anak balita di negara berkembang yang mendapatkan MP-ASI yang adekuat, yaitu frekuensi dan keragaman sesuai standar, sementara di Indonesia sebagian besar atau dua dari tiga anak usia 0-24 bulan tidak menerima MP-ASI yang tepat karena pola asuh yang salah (4). Praktik pemberian MP-ASI yang tidak optimal mempengaruhi asupan energi dan zat gizi. Hasil survei diet total (SDT) tahun 2014 menunjukkan hampir 1 dari 4 anak atau 24,7\% anak balita di Aceh mempunyai asupan protein kurang dan 6 dari 10 anak atau 60,4\% mempunyai asupan energi kurang dari angka kecukupan energi (AKE) yang dianjurkan (6).

Oleh karena itu, pemerintah telah merumuskan strategi penanggulangan stunting melalui intervensi spesifik dan sensitif, salah satunya melalui memberikan pendidikan pengasuhan pada orang tua dan pendidikan gizi masyarakat (4). Tujuan program ini adalah meningkatkan pengetahuan dan keterampilan orang tua dan pemahaman tentang praktik pengasuhan yang baik termasuk pemberian makanan. Hasil kajian gizi ibu dan anak oleh The United Nations Children's Fund (UNICEF) menunjukkan salah satu faktor yang mempengaruhi sulitnya melakukan pencegahan dan penanganan gizi kurang di Indonesia adalah pengetahuan yang tidak memadai dan berbagai praktik pemberian makanan yang tidak tepat (7).

Hasil studi di daerah surplus beras Jawa Tengah, menunjukkan 60\% ibu telah memberi makanan tambahan selain ASI pada usia kurang dari 6 bulan dan memberi makanan terlalu dini (8). Hasil studi di Semarang juga menunjukkan sebanyak 55,3\% bayi sudah diberi makanan pendamping lokal dan hampir semua bayi sudah diberi makanan padat pada usia kurang dari 6 bulan (9). Faktor yang mempengaruhi praktik pemberian makanan secara dini telah banyak diteliti yaitu pendidikan ibu yang rendah, pengaruh pendapat orang lain yang lebih tua, waktu anak bersama ibu yang singkat akibat bekerja di luar rumah (11). Hasil studi menyatakan bahwa ada kaitan faktor individu, kelompok, dan lingkungan sosial dengan praktik pemberian MP-ASI pada anak di Indonesia. Studi di Aceh menunjukkan hanya $40 \%$ atau hanya 4 dari 10 anak usia 6-23 bulan yang memenuhi pemberian MP-ASI yang adekuat, yaitu frekuensi sesuai standar dan beragam (10). Namun, faktor apa yang terkait dengan rendahnya praktik pemberian makanan pada anak di Aceh belum dilakukan.

Secara personal, perubahan perilaku dan praktik pemberian makanan dipengaruhi persepsi, nilai-nilai kepercayaan yang dianut, pemahaman, sikap normanorma sosial, kepercayaan diri (self eficacy), preferensi, dan sensori ketersediaan pangan dan lingkungan (11). Namun, perbedaan demografi, geografi, sosiokultural, dan lingkungan menyebabkan perbedaan faktor penyebab 
terjadinya perilaku sehingga diperlukan kajian secara spesifik melalui formative study yang dijadikan sebagai dasar dalam pengembangan intervensi edukasi (12). Studi formatif perlu dilakukan yang bertujuan untuk mengidentifikasi praktik pemberian makanan yang berlaku di masyarakat lokal, mengetahui hambatan, dan faktor pendukung pemberian MP-ASI yang optimal. Hasil studi formatif digunakan untuk pengembangan strategi program intervensi sera pengembangan pesan atau informasi kunci untuk edukasi sehingga diperoleh model intervensi yang sesuai dengan kondisi faktual sasaran intervensi (13).

Penelitian ini bertujuan untuk mengkaji faktor risiko antara lain pengetahun, sikap, motivasi ibu, dan faktor sosiodemografi terhadap praktik pemberian MPASI pada anak usia 6-24 bulan di Aceh. Hasil penelitian ini diharapkan dapat menjadi dasar dalam upaya penyusunan model edukasi gizi untuk meningkatkan praktik pemberian MP-ASI pada anak usia 6-23 bulan.

\section{BAHAN DAN METODE}

\section{Desain dan subjek}

Penelitian ini merupakan studi formatif dan bagian dari studi "Efektivitas model edukasi gizi dengan Kartu Monitoring Makanan (KMM) dan biskuit MP-ASI terhadap pertumbuhan dan status anemia pada anak gizi kurang di Aceh". Studi formatif ini menggunakan desain cross-sectional terhadap 392 sampel ibu yang mempunyai anak usia 6-23 bulan pada empat wilayah puskesmas di tiga kecamatan di Kabupaten Aceh Besar yang dilaksakanan pada bulan Mei sampai Juni 2016. Lokasi ditentukan secara purposive sampling berdasarkan prevalensi gizi kurang. Hasil Pemantauan Status Gizi (PSG) tahun 2014, prevalensi gizi kurang di Aceh Besar mencapai 28,0\% yang merupakan kabupaten tertinggi ketiga di Aceh (14). Penelitian ini sudah mendapatkan ethical approval dari Komisi Etik Fakultas Kedokteran Universitas Indonesia nomor: 452/UN.2.F1/ETIK/2016 dan setiap sampel diminta persetujuan menjadi sampel dengan menandatangani inform concent.

Sampel penelitian adalah ibu dari anak usia 6-23 bulan di tiga kecamatan terpilih dengan kriteria antara lain, 1) mempunyai anak berusia 6-23 bulan; dan 2) anak tidak sedang mengalami sakit berat/kelainan bawaan yang berpengaruh terhadap pemberian makanan. Jumlah sampel ditentukan dengan rumus besar sampel survei (15) berdasarkan $\mathrm{Z} 1-\alpha / 2=1,96(\alpha=0,05)$; jumlah populasi (N) 3.351 anak usia 6-23 bulan (16); presisi (d) 0,05 (5\%); dan proporsi anak gizi kurang sebesar 26,7\% (11) sehingga jumlah sampel yang dibutuhkan 146,6 anak dan dibulatkan menjadi 147 sampel. Selanjutnya, jumlah sampel minimal dikali dua untuk antisipasi desain effect dalam penelitian dengan cluster sampling (15), maka jumlah sampel menjadi 284 subjek. Namun, jumlah sampel yang diambil pada akhir penelitian sebesar 392 anak. Pengambilan sampel dilakukan dengan metode cluster random sampling yaitu desa atau posyandu sebagai cluster.

\section{Pengumpulan dan pengukuran data}

Data sosiodemografi. Data ini meliputi umur, pendidikan, pekerjaan ibu, tingkat pengeluaran keluarga per bulan, dan jumlah anggota keluarga dikumpulkan

Tabel 1. Item pertanyaan pengetahuan

\begin{tabular}{l}
\hline Pertanyaan pengetahuan \\
\hline Anjuran lama pemberian ASI \\
Usia pertama pemberian MP-ASI \\
Mengapa anak harus diberi MP-ASI \\
Bentuk makanan anak menurut umur \\
Jenis bahan makanan untuk keragaman \\
Contoh bahan makanan sumber protein hewani \\
Contoh bahan makanan sumber protein nabati \\
Jenis sayuran sumber vitamin A \\
Buah dan sayur sumber zat gizi \\
Standart keragaman konsumsi makan \\
Upaya meningkatkan energi pada makanan anak \\
Frekuensi makan \\
Tehnik/cara memberi makan anak \\
Tanda anak mengalami kurang gizi \\
Penyebab utama anak kurang gizi \\
Cara menyimpan makanan anak \\
Tindakan hygine dan sanitasi persiapan makan anak \\
Tindakan hygine dan sanitasi sebelum menyuapi anak \\
makan \\
Tindakan untuk menghindarkan makanan dari cemaran \\
Pemberian makanan ketika anak sakit \\
Suplementasi dan makanan fortifikasi \\
Contoh bahan makanan sumber zat besi \\
Cara memberi buah pada anak
\end{tabular}


dengan metode wawancara menggunakan kuesioner terstruktur.

Pengetahuan ibu. Data pengetahuan dikumpulkan dengan metode wawancara menggunakan kuesioner terstruktur (closed ended question) dalam bentuk multiple choice (Tabel 1) dengan 5 alternatif pilihan jawaban. Jawaban benar diberi skor 1 dan jika salah diberi skor 0 .

Sikap ibu. Data sikap dikumpulkan dengan metode wawancara menggunakan kuesioner terstruktur dengan 2 tipe pernyataan, yaitu pernyataan positif dan negatif (Tabel 2) menggunakan skala likert 5 poin (five point likert scale) dengan skor $1=$ sangat tidak setuju (STS); skor 2=tidak setuju (TS); skor 3=netral (N); skor 4=setuju (S); dan skor $5=$ sangat setuju (SS).

Motivasi ibu. Data motivasi dikumpulkan dengan metode wawancara menggunakan kuesioner terstruktur terdiri dari pertanyaan yang terkait faktor intrinsik dan ekstrinsik responden (Tabel 3) menggunakan skala likert 5 poin dengan skor $1=$ sangat tidak setuju (STS); skor

Tabel 2. Item pernyataan sikap

\begin{tabular}{l} 
Pernyataan sikap \\
\hline Pernyataan positif \\
ASI tetap diberikan pada anak sampai berumur 2 tahun \\
Mulai usia enam bulan anak sudah harus dimulai diberi \\
makanan \\
Anak sebaiknya diberi nasi, lauk hewani, lauk nabati, sayur \\
dan buah-buahan setiap hari \\
Untuk memenuhi kebutuhan gizi anak bubur diberikan lebih \\
kental \\
Anak perlu diberi sayuran berwarna hijau dan orange \\
Anak yang tidak cukup makan akan menderita kekurangan gizi \\
Sebelum dan sesudah memberi makan anak ibu harus mencuci \\
tangan dengan sabun \\
Anak diberi makanan beragam setiap hari \\
Memberi makan anak dengan cara menyenangkan seperti \\
diberi perhatian, sambil bermain dan diberi contoh cara makan \\
Pernyataan negatif \\
Anak cukup diberikan makan seadanya karena masih kecil \\
Anak usia 9-11 bulan diberi makanan dalam bentuk bubur \\
Kacang-kacangan tidak perlu diberikan pada anak karena \\
masih kecil \\
Jika anak tidak mau makan sebaiknya dibiarkan saja \\
Tidak perlu menutup makanan yang penting tidak ditaruh \\
ditempat yang kotor \\
Buah-buahan tidak perlu diberikan pada anak karena dapat \\
menyebabkan sakit perut \\
Memberi ikan yang banyak dapat menyebabkan kecacingan \\
\hline
\end{tabular}

2=tidak setuju (TS); skor 3=netral (N); skor 4=setuju (S); dan skor $5=$ sangat setuju (SS).

Selanjutnya, peneliti menghitung persentase skor pengetahuan, sikap, dan motivasi dari setiap pertanyaan dengan rumus persen skor item pertanyaan adalah jumlah jawaban benar dari seluruh responden dibagi dengan jumlah responden dikalikan 100 (17). Pengetahuan, sikap, dan motivasi ibu dikategorikan menjadi tiga berdasarkan persentase skor, yaitu kurang (skor $<60 \%$ ), sedang (60$79,9 \%$ ), dan baik ( $\geq 80 \%$ ) (18). Instrumen pengumpulan data berupa kuesioner terstruktur pengetahuan, sikap, dan motivasi diadopsi dan dikembangkan dari Food Agricultural Organization (FAO) (17) tentang guidelines for assesing nutrition-related knowladge, attitude and practices. Kuesioner yang telah disusun dilakukan uji validitas dan reliabilitas terhadap 35 sampel responden dengan hasil yaitu 8 dari 33 item pertanyaan dalam kuesioner pengetahuan tidak valid sehingga jumlah item yang digunakan 23 item pertanyaan. Sementara itu, 16 dari 22 item pertanyaan dalam kuesioner sikap yang valid

Tabel 3. Item pernyataan motivasi

\begin{tabular}{l}
\hline Pernyataan motivasi \\
\hline Faktor intrinsik \\
Memberi makan anak karena sudah menjadi tanggung jawab \\
sebagai orang tua \\
Memberi makan anak dengan sebaiknya agar anak tidak sakit \\
Memberi makan anak sebaik mungkin agar anak sehat \\
Saya senang memberi makan anak karena mau dimakan anak \\
Membujuk anak makan agar terpenuhi kecukupan gizinya \\
Memberi makan anak agar bisa tumbuh dan berkembang \\
Memberi makan anak agar bisa menjadi anak yang cerdas \\
Memberikan makanan beragam agar kebutuhan anak saya \\
dapat terpenuhi \\
Membuat makanan sebaik mungkin agar anak saya mau makan \\
sehingga cukup gizi \\
Faktor ektrinsik \\
Memberi makan anak karena anjuran dari petugas kesehatan \\
Memberi makan anak seperti bagaimana cara tetangga, teman \\
dan saudara \\
Memberi makan anak sesuai anjuran saya dapatkan dari \\
petugas kesehatan \\
Memberi makan kepada anak berdasarkan apa yang ibu/ \\
keluarga saya \\
Memberi makan anak berdasarkan anjuran-anjuran secara \\
turun-temurun di daerah kami \\
Memberikan makanan tertentu berdasarkan larangan atau \\
anjuran sesuai kebiasaan/budaya \\
\hline
\end{tabular}


dan 15 dari 18 item pertanyaan dalam kuesioner motivasi yang valid. Hasil analisis reliabilitas dengan Chroncbach alpha yaitu nilai r pengetahuan, sikap, dan motivasi secara berturut-turut adalah $\mathrm{r}=1,041 ; \mathrm{r}=0,850$; dan $\mathrm{r}=0,893$.

Praktik pemberian MP-ASI. Indikator kualitas praktik pemberian makanan pada anak usia dini yang direkomendasikan oleh WHO dan UNICEF $(1,17,19)$ yaitu, kesesuaian waktu pemberian MP-ASI (timely introduction complementary feeding), frekuensi makan (minimum meal frequency), keragaman (minimum dietary diversity), dan pemberian MP-ASI yang adekuat (minimum acceptable diet).

Indikator pertama, pengenalan MP-ASI tepat waktu (timely introduction of complementary feeding) yaitu persentase anak usia 6-23 bulan dengan pemberian MP-ASI semi padat dan padat tepat pada usia 6 bulan.

Indikator kedua, frekuensi konsumsi makanan (minimum meal frequency) yaitu proporsi anak usia 6-23 bulan yang mendapatkan makanan dengan frekuensi sesuai umur. Frekuensi makan bagi bayi yang masih diberikan ASI yaitu 2 kali/hari atau lebih untuk usia 6-8 bulan dan $3 \mathrm{kali} /$ hari atau lebih untuk anak usia 9-23 bulan sedangkan anak usia 6-23 bulan yang tidak diberi ASI, minimal 4 kali/hari atau lebih.

Indikator ketiga, keragaman (minimum dietary diversity) yaitu proporsi jumlah anak mendapatkan makanan lebih dari atau sama dengan empat jenis pangan dari kelompok pangan yang berbeda, yang meliputi 1) serealia dan umbi-umbian; 2) legum dan kacang-kacangan; 3) dairy products (susu, yoghurt, dan keju); 4) flesh foods (daging, ikan, unggas, dan hati/organ meats); 5) telur; 6) buah dan sayuran kaya provitamin A; 7) buah dan sayuran lainnya.

Indikator keempat, pemberian MP-ASI yang adekuat (minimum acceptable diet). Proporsi anak usia 6-23 bulan yang mendapatkan makanan dengan frekuensi sesuai umur dan beragam.

Praktik MP-ASI yang tepat (appropriate complementary feeding). Proporsi jumlah anak usia 6-23 bulan yang memenuhi kriteria dari empat variabel, yaitu pemberian MP-ASI tepat waktu, frekuensi sesuai, beragam, dan memenuhi kriteria minimum acceptable diet disebut praktik pemberian MP-ASI tepat sedangkan jika satu variabel saja tidak sesuai maka dikategorikan tidak tepat (17).

\section{Analisis data}

Analisis data menggunkan program IBM SPSS 21.0. Analisis dilakukan secara univariat untuk menggambarkan proporsi masing-masing variabel. Analisis hubungan pengetahuan dengan sikap dan motivasi menggunakan uji korelasi Pearson sedangkan untuk mengetahui hubungan variavel sosiodemografi dengan pengetahuan, sikap, dan motivasi serta praktik pemberian MP-ASI digunakan uji regresi logistik biner. Analisis odds ratio (OR) untuk mengetahui besaran risiko dari setiap variabel independen terhadap variabel dependen. Semua uji dilakukan pada tingkat kepercayaan $95 \%(\alpha=0,05)$.

\section{HASIL}

\section{Karakteristik responden}

Hasil penelitian menunjukkan sebagian besar responden berumur antara $25-35$ tahun $(59,7 \%)$, bekerja sebagai ibu rumah tangga $(92,1 \%)$, berpendidikan SLTA $(48,7 \%)$, dan jumlah anggota keluarga antara 3-4 orang $(54,6 \%)$ dengan pengeluaran keluarga per bulan antara Rp 1,9 juta sampai 3,5 juta (47,7\%) (Tabel 4).

\section{Pengetahuan, sikap dan motivasi ibu tentang pemberian MP-ASI}

Rerata persentase skor pengetahuan ibu tentang MP-ASI adalah 3,6 $\pm 19,3 \%$ dengan persen skor minimal 13,04\% dan tertinggi 100,0\%. Sebagian besar ibu mempunyai tingkat pengetahuan tentang MP-ASI pada kategori sedang $(45,4 \%)$ dan kurang $(34,4 \%)$ (Tabel 5). Hasil analisis data terhadap item pertanyaan dari pengetahuan menunjukkan bahwa dari 23 item pertanyaan pengetahuan, 7 item pertanyaan yang persentase menjawab benar masih rendah $(<60 \%)$ yaitu, upaya untuk meningkatkan kepadatan energi pada makanan anak (12,8\%), alasan perlunya anak diberi MP-ASI $(24,7 \%)$, keragaman makanan $(38,8 \%)$, frekuensi makan sehari $(38,8 \%)$, jenis bahan makanan $(45,2 \%)$, tanda anak mengalami kurang gizi $(45,9 \%)$, dan contoh bahan makanan sumber zat besi $(48,5 \%)$ sedangkan item pertanyaan lainnya sudah lebih dari $60 \%$ ibu yang menjawab dengan benar. 
Rerata skor dan persentase skor sikap ibu tentang pemberian MP-ASI adalah 71,9 $\pm 6,02 \%$ dengan skor minimal 50,0\% dan tertinggi 88,7\%. Sebagian besar ibu mempunyai sikap terhadap praktik pemberian MP-ASI pada kategori sedang (88,5\%) (Tabel 5). Hasil analisis terhadap item pertanyaan sikap dari sembilan pernyataan positif, hanya dua item dengan skor sikap yang rendah, yaitu anak diberi bubur yang lebih kental untuk memenuhi kebutuhan energi dan makanan anak harus beragam/ bervariasi. Sementara itu, rerata skor sikap ibu untuk

Tabel 4. Karakteristik responden $(\mathrm{n}=392)$

\begin{tabular}{lcc}
\hline Karakteristik & $\mathbf{n}$ & $\mathbf{\%}$ \\
\hline Umur ibu (tahun) & & \\
$\quad<25$ & 75 & 19,1 \\
$25-35$ & 234 & 59,7 \\
$\quad \geq 36$ & 83 & 21,2 \\
Pekerjaan ibu & & \\
$\quad$ Ibu rumah tangga & 361 & 92,1 \\
$\quad$ Bekerja di luar & 31 & 7,9 \\
Pendidikan & & \\
$\quad \leq$ Sekolah dasar (SD) & 37 & 9,4 \\
$\quad$ Tamat SLTP & 87 & 22,2 \\
$\quad$ Tamat SLTA & 191 & 48,7 \\
$\quad$ Diploma/Sarjana & 77 & 19,6 \\
Jumlah anggota keluarga (orang) & & \\
$\quad$ 3-4 & 214 & 54,6 \\
5-6 & 149 & 38,0 \\
$\quad \geq 7$ & 29 & 7,4 \\
Pengeluaran keluarga (Rp/bulan) & & \\
$\quad<1,9$ juta & 169 & 43,1 \\
1,9-3,5 juta & 187 & 47,7 \\
$\quad>3,5$ juta & 36 & 9,2 \\
\hline
\end{tabular}

Tabel 5. Tingkat pengetahuan, sikap, dan motivasi ibu tentang MP-ASI

\begin{tabular}{lcc}
\hline Variabel & $\mathbf{n}$ & $\mathbf{\%}$ \\
\hline Pengetahuan & & \\
Baik & 79 & 20,2 \\
Sedang & 178 & 45,4 \\
Kurang & 135 & 34,4 \\
Sikap & & \\
Baik & 34 & 8,7 \\
Sedang & 347 & 88,5 \\
Kurang & 11 & 2,8 \\
Motivasi & & \\
Tinggi & 133 & 33,9 \\
Sedang & 256 & 65,3 \\
Kurang & 3 & 0,8 \\
\hline
\end{tabular}

setiap pernyataan negatif tergolong rendah, artinya setuju dengan pernyataan.

Rerata persentase skor motivasi adalah $75,98 \pm 6,57 \%$ dengan persen skor terendah 53,33\% dan tertinggi 93,33\%. Sebagian besar ibu mempunyai motivasi dengan kategori sedang $(65,3 \%)$ dan hanya 33,9\% ibu yang mempunyai motivasi tinggi (Tabel 5). Hasil analisis rerata skor dari setiap item pernyataan motivasi dibedakan menjadi faktor instrinsik dan ekstrinsik yang menunjukkan bahwa seluruh item pernyataan intrinsik (9 item) mempunyai skor lebih dari 4 sedangkan rerata skor faktor ekstrinsik berada di antara 3,01 sampai 3,61. Artinya, faktor intrinsik lebih dominan mempengaruhi motivasi ibu untuk melakukan praktik pemberian MP-ASI dibandingkan faktor ekstrinsik yang berasal dari luar diri ibu.

\section{Kualitas praktik pemberian MP-ASI}

Pada penelitian ini, kualitas praktik pemberian MP-ASI dikategorikan berdasarkan empat dari delapan indikator yang direkomendasikan WHO $(1,17,19)$. Hasil penelitian menunjukkan kualitas praktik pemberian MPASI pada anak usia 6-23 bulan masih belum optimal, hanya kurang dari seperempat anak yang mempunyai praktik pemberian MP-ASI baik (23,4\%). Berdasarkan 4 indikator yang digunakan, hanya frekuensi makan (minimum meal frequency) yang paling tinggi (75,5\%) diikuti kesesuaian waktu pemberian MP-ASI (timely introduction complementary feeding) dan keragaman (minimim dietary diversity). Sementara itu, tingkat minimum acceptable diet masih sangat rendah sehingga mempengaruhi kualitas pemberian MP-ASI (appropriate complementary feeding) (Gambar 1).

\section{Hubungan karakteristik ibu dengan pengetahuan, sikap, dan motivasi}

Hasil pada Tabel 6 menunjukkan bahwa jumlah ibu dengan pengetahuan dan sikap yang tergolong kurang, lebih tinggi pada ibu yang berumur kurang dari 25 tahun (46,7\% dan 45,3\%); ibu yang bekerja (48,4\% dan $41,3 \%)$; paling tinggi (75,7\% dan $67,6 \%)$ pada ibu dengan pendidikan rendah $(\leq \mathrm{SD})$; dan pada ibu dengan pengeluaran keluarga per bulan kurang dari 1,9 juta rupiah 


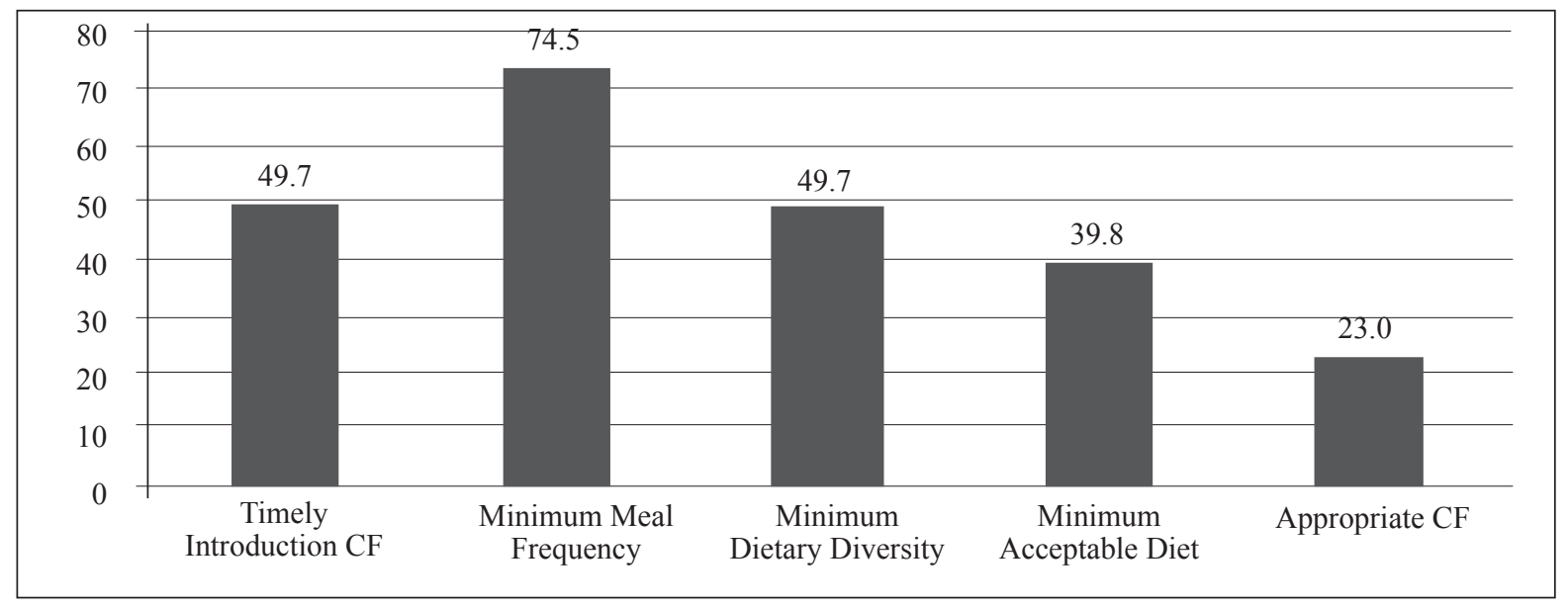

$\mathrm{CF}=$ complementary feeding

Gambar 1. Kualitas praktik pemberian makanan pendamping ASI (MP-ASI)

Tabel 6. Hubungan karakteristik dengan pengetahuan, sikap, dan motivasi ibu

\begin{tabular}{|c|c|c|c|c|c|c|}
\hline \multirow{2}{*}{ Karakteristik ibu } & \multicolumn{2}{|c|}{ Pengetahuan kurang } & \multicolumn{2}{|c|}{ Sikap kurang } & \multicolumn{2}{|c|}{ Motivasi rendah } \\
\hline & n (\%) & OR $(95 \% C I)$ & n (\%) & OR $(95 \% C I)$ & n (\%) & OR $(95 \% C I)$ \\
\hline \multicolumn{7}{|l|}{ Umur (tahun) } \\
\hline$<25$ & $35(46,7)$ & 1 & $34(45,3)$ & 1 & $34(45,3)$ & 1 \\
\hline $25-35$ & $92(39,3)$ & $0,72(0,37-1,40)$ & $90(38,5)$ & $0,88(0,46-1,70)$ & $109(46,6)$ & $0,41(0,20-0,83)$ \\
\hline$\geq 36$ & $36(43,4$ & $0,95(0,55-1,64)$ & $37(44,6)$ & $1,05(0,62-1,80)$ & $26(31,3)$ & $0,49(0,28-0,86)$ \\
\hline \multicolumn{7}{|l|}{ Pekerjaan } \\
\hline Bekerja & $15(48,4)$ & 1 & $12(38,7)$ & 1 & $15(48,4)$ & 1 \\
\hline Ibu rumah tangga & $148(41,0)$ & $0,45(0,19-1,04)$ & $149(41,3)$ & $0,70(0,30-1,65)$ & $154(42,7)$ & $1,36(0,60-3,06)$ \\
\hline \multicolumn{7}{|l|}{ Pendidikan } \\
\hline Diploma/PT & $20(26,0)$ & 1 & $16(20,8)$ & 1 & $43(55,8)$ & 1 \\
\hline SLTA & $71(37,2)$ & $10,20(3,92-26,50)^{*}$ & $82(42,9)$ & $8,24(3,28-20,70)^{*}$ & $75(39,3)$ & $0,85(0,36-2,01)$ \\
\hline SLTP & $44(50,6)$ & $5,22(2,42-12,56)^{*}$ & $38(43,7)$ & $2,81(1,31-6,01)^{*}$ & $36(41,4)$ & $1,43(0,66-3,07)$ \\
\hline$\leq \mathrm{SD}$ & $28(75,7)$ & $3,11(1,30-7,44)^{*}$ & $25(67,6)$ & $2,71(1,19-6,14)^{*}$ & $15(40,5)$ & $1,12(0,49-2,56)$ \\
\hline \multicolumn{7}{|c|}{ Pengeluaran rumah tangga } \\
\hline$>3,5$ juta & $14(39,8)$ & 1 & $16(44,4)$ & 1 & $21(58,3)$ & 1 \\
\hline $1,9-3,5$ juta & $71(38,0)$ & $1,15(0,51-2,55)$ & $68(36,4)$ & $0,83(0,38-1,82)$ & $99(52,9)$ & $0,24(010-0,53)$ \\
\hline$<1,9$ juta & $78(46,2)$ & $1,17(0,74-1,83)$ & $77(45,6)$ & $1,20(0,77-1,88)$ & $49(29,0)$ & $0,36(0,22-0,57)$ \\
\hline
\end{tabular}

*signifikan $(\mathrm{p}<0,001)$

(46,2\% dan 45,6\%). Hasil analisis dengan uji regresi logistik biner menunjukkan hubungan yang signifikan antara tingkat pendidikan ibu dengan pengetahuan dan sikap ibu. Semakin rendah pendidikan ibu, maka semakin tinggi proporsi ibu dengan pengetahuan kurang, yaitu 10,2 kali pada ibu dengan pendidikan SLTA; 5,2 kali pada ibu dengan pendidikan SLTP; dan 3,1 kali pada ibu yang berpendidikan rendah $(\leq \mathrm{SD})$ dibanding ibu dengan pendidikan tinggi $(\mathrm{p}=0,00 ; \mathrm{p}=0,00$; dan $\mathrm{p}=0,010)$.
Demikian juga untuk ibu dengan tingkat pendidikan SLTA, SLTP, dan SD berisiko lebih tinggi mempunyai sikap dengan kategori kurang dibandingkan ibu yang berpendidikan Diploma/Sarjana $(\mathrm{OR}=8,24, \mathrm{p}=0,00$; $\mathrm{OR}=2,81, \mathrm{p}=0,008$; dan $\mathrm{OR}=2,71, \mathrm{p}=0,017$ ).

Sementara itu, proporsi motivasi ibu dengan kategori kurang, lebih banyak pada ibu yang berusia 25 35 tahun dan diikuti usia kurang dari 25 tahun (46,6\% dan 45,3\%) dibandingkan ibu yang berusia lebih dari 
Tabel 7. Hubungan karakteristik, pengetahuan, sikap, dan motivasi terhadap praktik pemberian MP-ASI

\begin{tabular}{|c|c|c|c|}
\hline \multirow{2}{*}{$\begin{array}{c}\text { Variabel } \\
\text { independen }\end{array}$} & \multicolumn{2}{|c|}{$\begin{array}{c}\text { Praktik pemberian MPASI } \\
\text { kurang tepat }\end{array}$} & \multirow{2}{*}{$\mathbf{p}$} \\
\hline & n (\%) & OR 95\%CI & \\
\hline \multicolumn{4}{|l|}{ Umur (tahun) } \\
\hline$<25$ & $58(77,3)$ & 1 & \\
\hline $25-35$ & $180(76,9)$ & $0,92(0,42-2,01)$ & 0,845 \\
\hline$\geq 36$ & $64(77,1)$ & $0,90(0,48-1,70)$ & 0,764 \\
\hline \multicolumn{4}{|l|}{ Pekerjaan } \\
\hline Bekerja & $21(67,7)$ & 1 & \\
\hline Ibu rumah tangga & $281(77,8)$ & $1,76(0,72-4,28)$ & 0,209 \\
\hline \multicolumn{4}{|c|}{ Pendidikan } \\
\hline Diploma/PT & $54(70,1)$ & (1) & \\
\hline SLTA & $146(76,4)$ & $4,25(1,10-16,36)^{*}$ & $0,035^{*}$ \\
\hline SLTP & $68(78,2)$ & $3,26(0,92-11,55)$ & 0,066 \\
\hline$\leq \mathrm{SD}$ & $34(91,9)$ & $3,02(0,82-11,17)$ & 0,096 \\
\hline \multicolumn{4}{|c|}{ Pengeluaran rumah tangga } \\
\hline$>3,5$ juta & $31(86,1)$ & 1 & \\
\hline $1,9-3,5$ juta & $138(73,8)$ & $0,48(0,16-1,43)$ & 0,190 \\
\hline$<1,9$ juta & $133(78,7)$ & $1,27(0,75-2,17)$ & 0,364 \\
\hline \multicolumn{4}{|l|}{ Pengetahuan } \\
\hline Baik & $170(74,2)$ & 1 & \\
\hline Kurang & $132(81,0)$ & $1,15(0,63-2,10)$ & 0,633 \\
\hline \multicolumn{4}{|l|}{ Sikap } \\
\hline Baik & $132(82,0)$ & 1 & \\
\hline Kurang & $170(73,6)$ & $1,10(0,57-2,11)$ & 0,760 \\
\hline \multicolumn{4}{|l|}{ Motivasi } \\
\hline Tinggi & $166(74,4)$ & 1 & \\
\hline Rendah & $136(80,5)$ & $1,83(1,05-3,16)^{*}$ & $0,031 *$ \\
\hline
\end{tabular}

*signifikan $(\mathrm{p}<0,05)$

atau sama dengan 36 tahun. Artinya, terdapat hubungan yang negatif antara umur ibu dengan motivasi ibu atau semakin bertambah umur, maka semakin baik motivasi ibu. Ibu yang berusia 25-35 tahun dan lebih dari atau sama dengan 36 tahun mempunya motivasi kurang yang lebih kecil dibandingkan ibu yang berusia kurang dari 25 tahun $(\mathrm{OR}=0,41 ; \mathrm{p}=0,014$ dan $\mathrm{OR}=0,49 ; \mathrm{p}=0,014)$. Demikian juga terdapat hubungan negatif antara pengeluaran keluarga dengan motivasi ibu. Ibu dengan pengeluaran keluarga per bulan $\mathrm{Rp} 1,9-3,5$ juta $(\mathrm{OR}=0,24$ kali) dan kurang dari $\mathrm{Rp} 1,9$ juta per bulan $(\mathrm{OR}=0,36)$ lebih kecil risiko memiliki motivasi rendah dibandingkan ibu dengan pengeluaran keluarga per bulan lebih dari atau sama dengan $\mathrm{Rp} 3,6$ Juta ( $\mathrm{p}=0,00$ dan $\mathrm{p}=0,00)$. Artinya, ibu berpendapatan rendah cenderung memiliki motivasi yang lebih baik dalam pemberian MP-ASI dibandingkan ibu berendapatan lebih tinggi. Sementara berdasarkan pekerjaan dan tingkat pendidikan, tidak ada hubungan signifikan dengan motivasi ibu $(\mathrm{p}>0,05)$. Namun, terlihat ada kecenderungan lebih tinggi proporsi ibu yang mempunyai motivasi kurang pada ibu dengan pendidikan tinggi $(55,8 \%)$ dan ibu dengan pendidikan lebih rendah (SLTP dan $\leq$ SD) dibandingkan ibu dengan pendidikan pendidikan SLTA. Sebaliknya, ibu yang bekerja secara proporsi mempunyai motivasi kurang yang lebih tinggi $(48,4 \%)$ dibandingkan ibu yang bekerja sebagai ibu rumah tangga saja.

\section{Hubungan karakteristik, pengetahuan, sikap, dan motivasi terhadap praktik pemberian MP-ASI}

Hasil analisis pada Tabel 7 menunjukkan proporsi praktik pemberian MP-ASI yang tidak tepat, relatif hampir sama menurut umur ibu, tetapi pada ibu rumah tangga lebih tinggi $(77,8 \%)$ dibandingkan ibu yang bekerja $(67,7 \%)$. Berdasarkan tingkat pendidikan, proporsi ibu dengan praktik pemberian MP-ASI yang tidak tepat ditemukan lebih tinggi pada ibu berpendidikan rendah $(\leq \mathrm{SD})$ dibandingkan dengan pendidikan SLTP, SLTA, dan Diploma/Sarjana. Ibu dengan pendidikan SLTA, SLTP, dan $\leq$ SD berisiko lebih tinggi mempunyai praktik pemberian MP-ASI yang tidak tepat $(\mathrm{OR}=4,25$, $\mathrm{OR}=3,26$ dan $\mathrm{OR}=3,02$ ) dibandingkan ibu dengan pendidikan Diploma/Sarjana. Namun, hubungan yang signifikan hanya pada ibu dengan pendidikan SLTA $(p=0,035)$. Sementara berdasarkan pengeluaran keluarga per bulan, praktik pemberian MP-ASI yang tidak tepat ditemukan lebih tinggi pada ibu dengan pengeluaran per bulan lebih dari atau sama dengan 3,6 juta dibandingkan ibu dengan pengeluaran per bulan lebih rendah, tetapi tidak ada hubungan yang signifikan.

Lebih lanjut, proporsi praktik pemberian MPASI yang tidak tepat berdasarkan pengetahuan ibu, ditemukan lebih tinggi pada ibu dengan pengetahuan kategori yang kurang juga $(81,0 \%)$ dibandingkan ibu yang mempunyai pengetahuan baik $(74,2 \%)$ meskipun tidak signifikan secara statistik $(p=0,633)$. Sebaliknya, proporsi praktik pemberian MP-ASI yang tidak tepat ditemukan lebih tinggi pada ibu yang mempunyai sikap dengan kategori baik (82,0\%) dibandingkan ibu dengan sikap kategori kurang $(73,6 \%)$, tetapi juga tidak signifikan 
secara statistik $(\mathrm{p}=0,760)$. Berbeda dengan motivasi ibu yang menunjukkan hubungan signifikan dengan praktik pemberian MP-ASI, ibu dengan motivasi kurang akan lebih berisiko untuk mempunyai praktik pemberian MPASI yang tidak tepat $(\mathrm{OR}=1,83 ; \mathrm{p}=0,031)$.

\section{BAHASAN}

Hasil penelitian ini menunjukkan hanya sebagian kecil dari ibu atau pengasuh anak usia 6-23 bulan yang mempunyai pengetahuan, sikap, dan motivasi dengan kategori baik $(20,2 \% ; 8,7 \%$; dan 33,9\%). Kebanyakan ibu/pengasuh belum mengetahui beberapa aspek penting dari praktik pemberian MP-ASI yang direkomendasikan, yaitu pengetahuan tentang mengapa anak perlu diberi MP-ASI mulai usia 6 bulan, jenis dan keragaman, frekuensi dan upaya peningkatan energi, dan makanan sumber zat besi. Selain itu, masih banyak ibu/pengasuh dengan sikap kategori kurang pada aspek kekentalan bubur MP-ASI dan pemberian makanan yang beragam pada anak. Sementara itu, faktor dominan yang mempengaruhi motivasi ibu dalam pemberian MP-ASI berasal dari faktor internal dibandingkan faktor eksternal (petugas, keluarga, tetangga, dan sosial budaya). Kondisi ini terlihat dari rentang skor penilaian dengan skala likert yang berada di antara 3 sampai 3,61 sedangkan semua pernyataan pada skor faktor internal berada pada rentang nilai lebih dari atau sama dengan 4, yaitu adanya rasa tanggung jawab yang kuat mengasuh anak, adanya motivasi agar anak tercukupi kebutuhan gizi, serta mempunyai pertumbuhan yang baik dan sehat. Hasil penelitian ini juga menunjukkan bahwa hanya kurang dari seperempat $(23,4 \%)$ anak usia 6-23 bulan yang mempunyai praktik pemberian MP-ASI yang tepat (appropriate complementary feeding). Hasil analisis multivariat menunjukkan tingkat pendidikan ibu yang lebih rendah dan motivasi yang kurang berisiko mempunyai kualitas praktik pemberian MP-ASI yang tidak tepat. Hasil penelitian ini sejalan dengan studi sebelumnya bahwa pengetahuan, sikap, dan motivasi merupakan faktor personal yang mempengaruhi seseorang berperilaku, pengetahuan yang baik akan mempengaruhi pemahaman seseorang terhadap suatu masalah sehingga mempengaruhi bagaimana seseorang bersikap, selanjutnya akan mempengaruhi motivasi seseorang untuk melakukan atau tidak melakukan suatu tindakan (8).

Hasil penelitian ini juga sejalan dengan beberapa studi di berbagai negara terutama negara-negara berkembang yang praktik pemberian MP-ASI masih menjadi masalah, serta masih rendahnya pengetahuan, sikap, motivasi, dan praktik pemberian MP-ASI pada anak. Hasil studi di daerah pedesaan Provinsi Hebei China juga menunjukkan kondisi yang sama dengan penelitian ini, yaitu pengetahuan ibu tentang rekomendasi pemberian makanan dan praktik pemberian makanan pada anak 0-23 bulan masih kurang, hanya sekitar 1 dari 3 ibu yang mengetahui perlunya inisiasi menyusu dini (IMD) dan hanya 1 dari 5 ibu yang memberi makanan sesuai rekomendasi (20). Hasil studi lainnya pada masyarakat perkotaan di Lagos State Nigeria juga menunjukkan pengetahuan ibu tentang MP-ASI masih rendah yaitu hanya $14,9 \%$ ibu mempunyai pengetahuan baik. Beberapa aspek pengetahuan yang masih rendah hampir sama dengan penelitian ini yaitu pemahaman ibu tentang pengertian MP-ASI, usia anak seharusnya disapih, frekuensi konsumsi MP-ASI sehari, dan dampak pemberian MP-ASI terlambat. Proporsi praktik pemberian MP-ASI yang baik hanya $47 \%$, indikator keragaman, frekuensi, dan acceptable diet juga masih rendah (21). Demikian juga dengan hasil studi di daerah pedesaan Damot Sore District, Southern Ethiopia menunjukkan hanya $11,4 \%$ anak yang mendapatkan praktik pemberian MP-ASI yang baik (22). Bahkan, studi lain di Etiophia melaporkan hanya 9,5\% anak usia 12-17 bulan dan 18-23 bulan mendapatkan MP-ASI yang adekuat (23).

Hasil penelitian ini menunjukkan sebagian besar pengetahuan, sikap, dan motivasi ibu tentang praktik pemberian MP-ASI masih kurang, diikuti juga dengan kualitas praktik pemberian MP-ASI yang juga rendah. Berbeda dengan beberapa hasil studi di negara lain dengan kondisi yang sebaliknya, yaitu pengetahuan $\mathrm{ibu/pengasuh} \mathrm{tentang} \mathrm{praktik} \mathrm{pemberian} \mathrm{makanan} \mathrm{pada}$ anak sudah lebih baik, tetapi praktik pemberian MP-ASI masih rendah. Beberapa studi tersebut antara lain studi di Accra Ghana yang menunjukkan lebih dari $60 \%$ ibu mempunyai pengetahuan tentang praktik pemberian MP-ASI yang tepat, tetapi praktik pemberian MP-ASI 
masih sub-optimal yaitu hanya 32\% anak usia 6-23 bulan yang memenuhi kriteria minimum acceptable diet (24). Hasil studi di Philipina juga menunjukkan kondisi yang sama yaitu $66,7 \%$ ibu mempunyai tingkat pengetahuan yang tinggi, tetapi persentase asupan zat besi vitamin $\mathrm{A}$ dan vitamin $\mathrm{C}$ yang adekuat pada anak usia 6-11 bulan masih rendah (25).

Penelitian ini menemukan bahwa tingkat pendidikan dan motivasi ibu merupakan faktor risiko yang menyebabkan rendahnya kualitas praktik pemberian MP-ASI. Hasil ini didukung oleh beberapa studi lain, yaitu studi di Northern Ethiopia yang menyimpulkan bahwa salah satu faktor yang mempengaruhi adalah tingkat pendidikan (26). Pengetahuan, sikap, dan praktik pemberian makanan dapat ditingkatkan melalui edukasi yang terstruktur dan terarah. Hasil studi di Uganda menunjukkan pemberian edukasi gizi menyebabkan peningkatan signifikan terhadap pengetahuan ibu dalam menyiapkan makanan anak, sikap, dan praktik pemberian makanan (27). Demikian juga dengan hasil studi di Morogoro, Tanzania yang melaporkan pemberian edukasi gizi dapat meningkatkan skor komposite pengetahuan, artinya terjadi peningkatan pengetahuan gizi (28). Pengetahuan, sikap, dan motivasi yang baik akan mempengaruhi praktik pemberian MP-ASI dan berdampak pada asupan dan status gizi anak. Studi pada anak usia 0-12 bulan di Aceh menunjukkan asupan energi dan protein dari MP-ASI berhubungan dengan status gizi anak (29).

Di samping pengetahuan ibu, kualitas praktik MP-ASI juga dipengaruhi oleh multifaktor. Hasil studi di Ethiophia menunjukkan jumlah anggota keluarga dan tingkat pendidikan ibu sebagai faktor independen yang berpengaruh terhadap kualitas praktik pemberian MP-ASI (23). Studi lain di Ethiophia melaporkan lebih banyak faktor, yaitu pengambilan keputusan tentang pemberian makanan oleh ayah, prioritas pemberian makanan pada orang yang lebih tua dalam keluarga, tidak tersedia fasilitas pelayanan kesehatan terdekat, kehamilan yang tidak direncanakan, tidak mendapatkan pelayanan antenatal, dan kurangnya pemanfaatan pelayanan kesehatan merupakan faktor risiko rendahnya kualitas praktik MP-ASI (30). Faktor berbeda yang dilaporkan menurut hasil studi di Pakistan adalah faktor individu, yaitu anak usia 6-11 bulan dan pemeriksaan postnatal yang terlambat, serta faktor pada tingkat kelompok/komunitas, yaitu kondisi geografis, akses terhadap pelayanan kesehatan ibu dan anak serta tingkat kemiskinan merupakan faktor yang signifikan mempengaruhi praktik pemberian MP-ASI yang tidak optimal (31).

Hasil studi di Brazil menyimpulkan bahwa tidak memberikan ASI pada satu jam pertama kelahiran merupakan faktor risko pemberian cairan pada anak. Studi tersebut menggunakan indeks water, assets, mother's education and income (WAMI index) untuk mengukur status sosial ekonomi, yang terdiri dari sanitasi air, kepemilikan aset, pendidikan ibu, dan pendapatan keluarga yang merupakan faktor risiko pemberian makanan selain ASI pada usia 8 bulan pertama kehidupan (32). Studi lain di Malawi melaporkan bahwa pendidikan ibu yang tergolong menengah, bekerja, dan tinggal di daerah pertanian mempunyai praktik pengenalan makanan padat lebih tepat. Ibu/pengasuh yang berusia lebih dari 24 tahun dan berpendidikan dasar-menengah mempunyai keragaman konsumsi lebih baik, serta anak dari keluarga kaya lebih banyak yang mencapai praktik MP-ASI yang baik. Di samping itu, paparan media massa berkaitan dengan tercapainya praktik pemberian MP-ASI pada indikator frekuensi, keragaman, dan minimum acceptable diet (33). Hasil sistematik review menemukan bahwa hampir semua studi yang dilakukan tentang praktik pemberian MP-ASI menunjukkan praktik pemberian MP-ASI masih sub-optimal, faktor yang dominan mempengaruhi adalah kurangnya pengetahuan, tingkat pendidikan ibu yang rendah, sosial ekonomi, dan nilai budaya masyarakat (34).

Rendahnya kualitas praktik pemberian MP-ASI di Aceh terkait dengan berbagai faktor, tetapi hasil penelitian ini hanya menemukan tingkat pendidikan ibu dan kurangnya motivasi sebagai faktor yang signifikan untuk risiko praktik pemberian MP-ASI. Berdasarkan hasil penelitian ini diperoleh kesimpulan bahwa salah satu upaya perbaikan praktik pemberian MP-ASI di Aceh adalah melalui peningkatan tingkat pendidikan atau minimal meningkatkan pengetahuan melalui program promosi dan edukasi spesifik tentang praktik pemberian MP-ASI serta program edukasi yang lebih spesifik untuk 
meningkatkan motivasi ibu. Dengan demikian, perlu dikembangkan model edukasi gizi yang spesifik untuk meningkatkan dan mendorong motivasi ibu dengan mengadopsi metode perubahan perilaku yang sesuai dengan karakteristik sosial budaya masyarakat Aceh. Salah satu teori perubahan perilaku yang dapat digunakan adalah teori plan behavior. Teori ini menyebutkan bahwa perubahan perilaku dilakukan melalui peningkatan pengetahuan, sikap, persepsi, kontrol perilaku, motivasi, dan niat seseorang untuk berperilaku (8). Hasil studi yang mengkaji perbandingan beberapa rancangan intervensi perubahan perilaku di Bangladesh, Malawi, Peru, dan Zambia menyimpulkan bahwa penggunaan pendekatan perubahan perilaku dengan platform penyampaian pesan yang jelas dan terarah dapat meningkatkan praktik pemberian MP-ASI (35). Pemberian intervensi edukasi yang tepat akan membantu meningkatkan perubahan perilaku. Hasil studi intervensi paket edukasi gizi dapat meningkatkan praktik pemberian MP-ASI, asupan gizi yang adekuat, dan pertumbuhan anak di daerah pedesaan Tanzania (36).

Penelitian ini masih terbatas menggali beberapa faktor terkait sosiodemografi keluarga dan faktor tekait individu yaitu pengetahuan, sikap, dan motivasi ibu/ pengasuh di Aceh. Namun, faktor terkait kelompok dan masyarakat seperti sosial budaya, pengaruh lingkungan keluarga, dan masyarakat serta peran dari petugas kesehatan belum dikaji. Hasil penelitian ini dapat dijadikan dasar dalam pengembangan model dan strategi intervensi edukasi gizi secara spesifik menggunakan pendekatan strategi perubahan perilaku yang tepat dan disesuaikan dengan kondisi spesifik lokal, karakteristik sosiodemografi, dan sosial budaya masyarakat Aceh dengan tujuan meningkatkan pengetahuan, sikap, dan motivasi ibu/pengasuh dalam praktik pemberian MP-ASI.

\section{SIMPULAN DAN SARAN}

Pengetahuan, sikap, dan motivasi ibu terkait praktik pemberian MP-ASI masih tergolong rendah. Hanya sekitar 1 dari 4 ibu yang mempunyai pengetahuan dan sikap yang baik sedangkan hanya 1 dari 3 ibu yang mempunyai motivasi tinggi tentang praktik pemberian MP-ASI. Praktik pemberian MP-ASI pada anak usia 6-23 bulan masih kurang optimal. Hanya 1 dari 4 anak yang mendapatkan praktik pemberian MP-ASI yang tepat, yaitu yang memenuhi kriteria usia pertama pemberian MP-ASI yang tepat, frekuensi, dan keragaman. Perlu upaya serius untuk meningkatkan pengetahuan, sikap, dan motivasi ibu melalui program edukasi yang spesifik dan terstruktur oleh petugas kesehatan dan pihak terkait terutama pada ibu dengan tingkat pendidikan yang rendah. Perlu mengembangkan model edukasi gizi yang mengacu pada strategi perubahan perilaku yang sesuai, penyampaian pesan yang jelas dan terstruktur, menggunakan pendekatan saluran komunikasi yang tepat, media dan alat/tools edukasi yang sederhana sehingga mudah dipahami, serta fasilitator yang terlatih sehingga dapat meningkatkan praktik pemberian MP-ASI sesuai rekomendasi.

\section{UCAPAN TERIMA KASIH}

Peneliti mengucapakan terima kasih kepada Danone Institute Indonesia yang telah membantu biaya penelitian melalui Doctorate Research Grant.

\section{Pernyataan konflik kepentingan}

Peneliti dengan ini menyatakan tidak ada konflik kepentingan dalam pelaksanaan penelitian ini.

\section{RUJUKAN}

1. World Health Organization. Infant and young child feeding; model chapter for textbook for medical student and allied health profesional. Geneva, Switzerland: WHO; 2009.

2. Direktorat Bina Gizi Masyarakat. Modul pelatihan konseling MP-ASI (panduan peserta). Jakarta: Direktorat Bina Gizi Masyarakat, Kemenkes RI; 2010.

3. Stewart CP, Iannotti L, Dewey KG, Michaelsen KF, Onyango AW. Contextualising complementary feeding in a broader framework for stunting prevention. Matern Child Nutr. 2013;9(Suppl.2):27-45. https://doi.org/10.1111/ men. 12088

4. Tim Nasional Percepatan Penanggulangan Kemiskinan (TNPK). 100 Kabupaten/Kota prioritas untuk intervensi anak kerdil (stunting). Jakarta: Sekretriat Wakil Presiden RI; 2017.

5. Badan Penelitian dan Pengembangan Kesehatan. Laporan riset kesehatan dasar tahun 2018. Jakarta: Balitbangkes Kemenkes RI; 2018. 
6. Kartono D, Hermina, Faatih M. Buku studi diet total: survei konsumsi makanan individu Provinsi Aceh 2014. Jakarta: Balitbangkes RI; 2014.

7. United Nation Children Fund Indonesia (UNICEF). Ringkasan kajian gizi ibu dan anak: isu-isu penting. [series online] 2012 [cited 2014 Des 20]. Available online: URL: http://www.unicef.or.id/

8. Barati Z, Purwestri RC, Wirawan NN, Beitze DE, Srour L, Scherbaum V. Breastfeeding and complementary feeding practices among children living in a rice surplus area, Central Java, Indonesia. Nutrition \& Food Science 2018;48(4):589-604. https://doi.org/10.1108/NFS-072017-0144

9. Suyatno. The impact of complementary feeding type on the nutritional status of infant 6-12 months of age in Suburban Semarang Indonesia. Proceedings of International Conference on Applied Science and Health 2017: Improving health and well-being for better society. [series online] 2017 [cited 2018 Des 20]. Available online: URL: https://publications.inschool.id/index.php/icash/ article/view/58/57

10. Ahmad A, Madanijah S, Dwiriani CM, Kolopaking R. Complementary feeding practices and nutritional status of children 6-23 months old: formative study in Aceh, Indonesia. Nutr Res Pract. 2018;12(6):512-20. https://doi. org/10.4162/nrp.2018.12.6.512

11. Contento IR. Nutrition education: lingking theory and practice. 2 ed. Canada: Jones and Bartlett Publisher; 2011.

12. Bentley ME, Johnson SL, Wasser H, Kanashiro HC, Shroff M, Cunningham M, et al. Formative research methods for designing culturally appropriate, integrated child nutrition and development interventions: An overview. Ann N Y Acad Sci. 2014;(1)1308:54-67. https://doi.org/10.1111/nyas.12290

13. Fabrizio CS, Liere MV, Pelto G. Identifying determinants of effective complementary feeding behaviour change interventions in developing countries. Matern Child Nutr. 2014;10(4):575-92. https://doi.org/10.1111/mcn.12119

14. Dinas Kesehatan Aceh. Hasil survei pemantauan status gizi (PSG) Provinsi Aceh Tahun 2014: monitoring dan evaluasi program. Banda Aceh: Dinkes Aceh dan Jurusan Gizi Poltekkes Aceh; 2015.

15. Lameshow S, Hosmer DW, Klar J, Lwanga SK. Adequacy sample size in health studies. New York: John Wiley \& Sons Ltd; 1990.

16. Dinas Kesehatan Aceh Besar. Laporan bulan penimbangan balita di posyandu. Aceh: Dinkes Aceh Besar; 2015.

17. Food Agricultural Organization (FAO) of The United Nation. Guidelines for assesing nutrition-related knowledge, attitudes and practices. [series online] 2012 [cited 2014 Des 20]. Available online: URL: http://www. fao.org/3/a-i3545e.pdf
18. Khomsan A. Teknik pengukuran pengetahuan gizi. Bogor; Institut Pertanian Bogor; 2000.

19. PAHO, WHO, UNICEF. ProPAN: process for the promotion of child feeding. 2 ed. [series online] 2013 [cited 2015 November 29]. Available online: URL: https://www. paho.org/hq/dmdocuments/2013/Propan2-Eng.pdf

20. World Health Organization. Resolution WHA65.6. Maternal, infant and young child nutrition. In: Sixty-fifth World Health Assembly (WHA65/2012/REC/1). [series online] 2012 [cited 2015 November 29]. Available online: URL: http://apps.who. int/gb/DGNP/pdf_files/A65_REC1-en.pdf

21. Olatona FA, Adenihun JO, Aderibigbe SA, Adeniyi OF. Complementary feeding knowledge, practices, and dietary diversity among mothers of under-five children in an urban community in Lagos State, Nigeria. Int J MCH AIDS. 2017;6(1):46-59. https://doi.org/10.21106/ijma.203

22. Areja A, Yohannes D, Yohannis M. Determinants of appropriate complementary feeding practice among mothers having children 6-23 months of age in rural Damot sore district, Southern Ethiopia; a community based crosssectional study. BMC Nutrition. 2017;3:82. https:// doi.org/10.1186/s40795-017-0202-y

23. Kassa T, Meshesha M, Haji J, Ebrahim J. Appropriate complementary feeding practices and associated factors among mothers of children age 6-23 months in Southern Ethiopia, 2015. BMC Pediatr. 2016;16:131. https://doi. org/10.1186/s12887-016-0675-x

24. Gyampoh S, Otoo GE, Aryeetey RNO. Child feeding knowledge and practices among women participating in growth monitoring and promotion in Accra, Ghana. BMC Pregnancy and Childbirth. 2014;14:180. https://oi. org/10.1186/1471-2393-14-180

25. Dumaguing NV, Ignacio JLC, Naupal RT, Apostol NES, Ilagan JR, Talavera MTM. Knowledge, attitude, and practices of complementary feeding by mothers in the Bayanijuan Southville 7 Resettlement Village in Calauan, Laguna, Philippines. Journal of Human Ecology. 2011;1(1):58-72.

26. Mekbib E, Shumey A, Ferede S, Haile F. Magnitude and factors associated with appropriate complementary feeding among mothers having children 6-23 months-of-age in Northern Ethiopia; a community-based cross-sectional study. J Food Nutr Sci. 2014;2(2):36-42. doi: 10.11648/j. jfns.20140202.13

27. Nabugoomu J, Namutebi A, Kaaya AN, Nasinyama G. Nutrition education influences child feeding knowledge attitudes and practices of caregivers in Uganda. American Journal of Health Research. 2015;3(2):82-90. doi: 10.11648/j.ajhr.20150302.15

28. Pillai A, Kinabo J, Krawinkel MB. Effect of nutrition education on the knowledge scores of urban households 
with home gardens in Morogoro, Tanzania. Agric \& Food Secur. 2016;5:22. https://doi.org/10.1186/s40066-0160069-1

29. Ahmad A, Boediman D, Prawirohartono EP. Pola makanan pendamping air susu ibu dan status gizi bayi 0-12 bulan di Kecamatan Lhoknga Kabupaten Aceh Besar. Jurnal Gizi Klinik Indonesia. 2006;3(1). https://doi.org/10.22146/ ijcn. 17419

30. Berhanu Z, Alemu T, Argaw D. Predictors of inappropriate complementary feeding practice among children aged 6 to 23 months in Wonago District, South Ethiopia, 2017; case control study. BMC Pediatr. 2019; 19:146. https:// doi.org/10.1186/s12887-019-1523-6

31. Na M, Aguayo VM, Arimond M, Stewart CP. Risk factors of poor complementary feeding practices in Pakistani children aged 6-23 months: A multilevel analysis of the Demographic and Health Survey 2012-2013. Matern Child Nutr. 2017;13(S2):e12463. https://doi.org/10.1111/ mcn. 12463

32. Maciel BLL, Moraes ML, Soares AM, Cruz IFS, de Andrade MIR, Lima AAM, et al. Infant feeding practices and determinant variables for early complementary feeding in the first 8 months of life: results from the Brazilian MALED cohort site. Public Health Nutrition. 2018;21(13):2462-
70. https://doi.org/10.1017/S136898001800099X

33. Nkoka O, Mhone TG, Ntenda PAM. Factors associated with complementary feeding practices among children aged 6-23 mo in Malawi: an analysis of the Demographic and Health Survey 2015-2016. Int Health. 2018;10(6):46679. https://doi.org/10.1093/inthealth/ihy047

34. Manikam L, Sharmila A, Dharmaratnam A, Alexander EC, Kuah JY, Lakhanpaul M, et al. Systematic review of infant and young child complementary feeding practices in South Asian families: the Pakistan perspective. Public Health Nutr. 2018;21(4):655-68. https://doi.org/10.1017/ S1368980017002956

35. Sanghvi T, Seidel R, Baker J, Jimerson A. Using behavior change approaches to improve complementary feeding practices. Matern Child Nutr. 2017;13(S2):e12406. https:// doi.org/10.1111/men.12406

36. Kulwa KBM, Verstraeten R, Bouckaert KP, Mamiro1 PS, Kolsteren PW, Lachat C. Effectiveness of a nutrition education package in improving feeding practices, dietary adequacy and growth of infants and young children in rural Tanzania: rationale, design and methods of a cluster randomised trial. BMC Public Health 2014;14:1077. https://doi.org/10.1186/1471-2458-14-1077 